\title{
Status of buffalo farmers and buffaloes at Subornochar upozila of Noakhali district in Bangladesh
}

\author{
MR Amin ${ }^{1}$, MA Siddiki ${ }^{1}$, AKMA Kabir ${ }^{1}$, MO Faruque ${ }^{2}$, ZH Khandaker ${ }^{3}$ \\ ${ }^{1}$ Department of Animal Science; ${ }^{2}$ Department of Animal Breeding and Genetics; ${ }^{3}$ Department of Animal \\ Nutrition, Bangladesh Agricultural University, Mymensingh 2202, Bangladesh
}

\begin{abstract}
The aim of the study was designed to investigate the socio-economic status of buffalo farmers, productive and reproductive performances and management practices of buffaloes at different villages of Subornochar upozila of Noakhali district in Bangladesh. For this investigation total one hundred buffalo farmers were selected from ten villages. Ten farmers who have at least five buffaloes were randomly selected from each village. The investigation revealed that majority of the buffalo farmers age was ranged from 41 to 50 years followed by 51 to 55 years and less than 40 years. Hundred percent farmers were educated but no farmers were found who completed graduation. More than half of the farmers have primary educated followed by SSC or above and rest of them could sign only. In the study area, sixty eight percent of the buffalo farmers were engaged with agriculture along with buffalo rearing and rests of them were engaged with other business. More than half of the respondents were holding land above ten acres, followed by seven to ten acres and rest of them below three acres. Sixty five percent of the farmers took bank loan and rest of them used own capital and/or NGO's loan for rearing buffaloes. There were no farmers found who got training on buffalo rearing. More than two third of the respondents practiced buffalo rearing as their family profession and rest of them were influenced by the neighboring farmers. The buffalo breed of this area was mostly indigenous types. The highest numbers of buffaloes found were heifer followed by milking buffalo and buffalo bull calves. About half of the farmers kept their buffaloes at least two years followed by three and one years and rest of them was more than three years.The average milk production of indigenous buffalo was 2.7 liter/day. Birth weight, weaning weight, weaning and slaughter age of indigenous buffalo in the selected areas were $27.5 \mathrm{~kg}, 56.5 \mathrm{~kg}$ and 14 and 55 months, respectively. The average age at first heat that was puberty of buffaloes was 3.4 years. The gestation period, number of service per conception, post partum hear period and inter calving period was 10 months, 3.1times, 4.5 and 15.8 months, respectively. Most of the farmers maintain their buffaloes mainly in extensive system and bathan (80\%). Majority of the farmers (70\%) expressed availability of the feeds and fodder as the major problem for buffalo rearing. Out of locally available feeds and fodders rice straw, pasture grasses and Uri grass were the main source of feeds for buffaloes in selected areas. Uri grasses was very soft, very high in CP content and were commonly available in the bank of river or see shore. Buffalo farmers were not practicing to supply concentrate feeds to their buffaloes. Four major diseases of buffaloes were found where the incidence of foot and mouth diseases was high (63\%). Farmers of the selected area were totally unaware about vaccination and de-worming and they did not follow any vaccination and de-warming programme. They sale their buffaloes to the farmers or butcher and average cost of a pair of buffalo was Tk. 80,000.00 to Tk. 180,000.00. The annual cost of production per buffalo was Tk. 6350.00 while a gross return per buffalo was Tk. 13932.00. The annual food purchasing capacity of the buffalo farmers was increased 58\%. The educational, social status, health care and housing cost of the buffalo farmers were also increased through buffalo rearing. Considering all this parameters related to livelihood, it was clearly found that the socio-economic status of the buffalo farmers was improved through buffalo rearing.
\end{abstract}

Key words: Socio-economic status, buffalo, buffalo farmer, productive and reproductive performance 


\section{Introduction}

Bangladesh is one of the highest densities of livestock populated country in the world, of them 145 large ruminants per $\mathrm{km}^{2}$ compared with 94 for India, 30 for Ethiopia and 20 for Brazil (NARS, 2010). Buffalo population in this country is 1.62 million and is contributing through the production of 3500 and 22400 ton meat and milk respectively per year (DLS, 2013). Buffaloes hold strategic place in overall livestock economy of Bangladesh and serve three important purposes such as milk, meat and drought power supply (Ghaffar et al., 1991). The primary reasons for the selection of subornochar area is based on country's topography, ecology and buffalo production system, concentration of buffaloes, communication facilities etc. with the expectation to obtain reliable information. Buffaloes have a number of advantages are better converters of poor-quality fibrous feeds to produce more protein and to gain more body weight, more disease resistance, power and outstanding draught capacity and longer life span, milk and meat, with better degradation of both crude protein and protein free dry matter than cattle (Terramoccia et al., 2000). Other works have also indicated that buffaloes have a better digestive ability than cattle to utilize poor quality roughage (Hussain and Cheeke, 1996; Bartocci et al., 1997; Agarwal et al., 2008). The contribution of agriculture and livestock sub-sector to gross domestic product was 18.89 and 19.29 and 2.57 and 2.49 percent in FY 2010-2011 and 20112012 respectively (BER, 2012, accessed, 2015) and $13 \%$ of the total foreign exchange earnings from this sector (BBS, 2012). Buffalo has some significant importance on livelihoods improvement. Buffalo rearing increase livelihood status of the farmers especially for the farm women and development of this sector is the potential path to rural prosperity (Kalash et al., 2009; Sarker et al., 2013). In Bangladesh, the role of buffaloes is not emphasized and the species did not receive the attention of the policy makers and the researchers in accordance with its merits. Very little work has been done so far on the socio-economic status of the buffalo farmers and the management practices of buffalos in Bangladesh. Therefore, considering the above discussion, the present investigation was undertaken to know the socio-economic status; productive and reproductive performances of buffalos and livelihood changes of the buffalo farmers in some selected areas at Subornochar upozila of Noakhali district in Bangladesh.

\section{Materials and Methods}

\section{Selection of study areas and respondents}

A survey was conducted at Subornochar upozila of Noakhali district in Bangladesh during the months of July to September, 2011. Total one hundred buffalo farmers were selected from ten villages. Ten farmers were randomly selected from each village that has at least five buffaloes.

\section{Collection of data and measurement of variables}

The primary information was collected on pretested questionnaires through personal interview on socioeconomic characteristics of buffalo farmers (age, education, occupation, land holding, source of capital), buffalo holding size (types of buffaloes, duration of rearing). Production (birth weight, weaning weight, weaning age, slaughter age, milk production ) and reproduction status (age at first heat, first pregnancy, first calving, gestation period, number of service per conception, post partum heat period, inter calving period). Health care practices (incidence of diseases and health care), and feeding system (feeds and fodder availability, sources of feed, feeding methods). Cost benefit of buffalo rearing, impact and livelihood improvement of farmers toward buffalo husbandry was also investigated.

\section{Collection, preparation and chemical analysis of available feeds and fodders}

Proximate composition of some locally available feeds and fodders fed to buffaloes were collected to investigate their nutritional contents such as organic matter (OM), crude protein (CP), crude fiber (CF), ether extract (EE), nitrogen free extract (NFE), ash. Neutral detergent fibre (NDF) and Acid detergent fibre (ADF) were estimated by fibretec systems (VELP Scientifica, EU) following the procedure of 
Georing and Van Soest (1970). Samples of feeds \& fodder were collected from the selected area, mixed thoroughly, sun dried and ground at the size of 0.5 $\mathrm{mm}$ for chemical analysis according to the methods of AOAC (2004).

\section{Statistical analysis}

All the collected data were checked and cross checked before transferring to master sheets. The data was analyzed with the help of SPSS-v-16 computer package program.

\section{Results and Discussion}

\section{Socio-economic condition of buffalo farmers}

The socio economic condition of buffalo farmers are presented in Table 1 . The majority of the buffalo farmer's age was ranged from 41 to 50 years followed by 51 to 55 years and less than 40 years. Hundred percent farmers were educated but no farmers were found who completed graduation. More than half of the farmers have primary educated followed by SSC or above and rest of them could sign only. The education level of buffalo farmers was reported to be $91.82 \%$ and $56.1 \%$ in Bihar (Singh et al., 2011) and Jharkhand (Singh et al., 2012), respectively. In the study area, sixty eight percent of the buffalo farmers were engaged with agriculture along with buffalo rearing and rests of them were engaged with other business. Sarker et al., (2013) reported that $30 \%$ of the buffalo farmers of Bagerhat Districts in Bangladesh were fully depended on buffalo rearing. More than half of the respondents are holding land above ten acres, followed by seven to ten acres and rest of them below three acres. More than half of the respondents belonged to medium income categories followed by high and low income categories. In India, majority (96.92\%) of the respondents belonged to low family income categories (Sathyanarayan et. al., 2010). Sixty five percent of the farmers took bank loan and rest of them used own capital and/or NGO's loan for rearing buffaloes. There were no farmers found who got training on buffalo rearing. More than two third of the respondents practiced buffalo rearing as their family profession and rest of them were influenced by the neighboring farmers.
Table 1. Socio economic condition of buffalo farmers in Subornochar

\begin{tabular}{|c|c|c|}
\hline Parameters & Category & $\begin{array}{c}\text { Percentage of } \\
\text { respondents }\end{array}$ \\
\hline \multirow{5}{*}{ Age } & Below 40 & 13 \\
\hline & $41-50$ & 65 \\
\hline & $51-55$ & 17 \\
\hline & Above 56 & 5 \\
\hline & Total & 100 \\
\hline \multirow{5}{*}{ Education } & Can sign only & 5 \\
\hline & Primary & 38 \\
\hline & Below SSC & 25 \\
\hline & SSC or above & 31 \\
\hline & Total & 100 \\
\hline \multirow{3}{*}{ Occupation } & Principle (agriculture) & 68 \\
\hline & Other & 32 \\
\hline & Total & 100 \\
\hline \multirow{5}{*}{$\begin{array}{l}\text { Land holding } \\
\text { (land in acres) }\end{array}$} & $1-2$ & 5 \\
\hline & $3-6$ & 10 \\
\hline & $7-10$ & 30 \\
\hline & Above 10 & 55 \\
\hline & Total & 100 \\
\hline \multirow{4}{*}{$\begin{array}{l}\text { Annual Income } \\
\text { (Tk. in lac) }\end{array}$} & Low (below 1) & 17 \\
\hline & Medium (1 to 4 ) & 56 \\
\hline & High (above 4) & 30 \\
\hline & Total & 100 \\
\hline \multirow{3}{*}{ Source of capital } & From bank loan & 65 \\
\hline & Own capital & 35 \\
\hline & Total & 100 \\
\hline \multirow{4}{*}{ Training skill } & With training & 00 \\
\hline & Without training & 77 \\
\hline & Influence by neighbor & 23 \\
\hline & Total & 100 \\
\hline
\end{tabular}

\section{Buffalo holding size and duration of rearing}

Buffalo holding size like types of buffalo and duration of rearing buffaloes are presented in Table 2. The buffalo breeds of this area were mostly indigenous types. The highest numbers of buffaloes found were heifer followed by milking buffalo and buffalo bull calves. About half of the farmers kept their buffaloes at least two years followed by three and one years and rest of them was more than three years.

\section{Performances status of buffaloes}

\section{Productive performances}

The average milk productions of indigenous buffaloes were 2.7 liter/day. Gupta et al., (2014) reported that daily milk production of non-descript 
Table 2. Distribution of buffaloes in selected area of Subornochar

\begin{tabular}{|c|c|c|}
\hline Parameters & Category & $\begin{array}{c}\text { Percentage of } \\
\text { respondents }\end{array}$ \\
\hline \multirow{7}{*}{$\begin{array}{l}\text { Types of } \\
\text { buffaloes }\end{array}$} & Indigenous Milking Buffalo & 23 \\
\hline & Indigenous Heifer Buffalo & 54 \\
\hline & Indigenous Buffalo Bull & 21 \\
\hline & Crossbred Milking Buffalo & 0.86 \\
\hline & Crossbred Heifer Buffalo & 0.86 \\
\hline & Crossbred Bull buffalo & 0.28 \\
\hline & Total & 100 \\
\hline \multirow{5}{*}{$\begin{array}{c}\text { Duration of } \\
\text { rearing }\end{array}$} & 1 year & 13 \\
\hline & 2 years & 45 \\
\hline & 3 years & 32 \\
\hline & Above 3 years & 10 \\
\hline & Total & 100 \\
\hline
\end{tabular}

cows in the eastern region of India varied from 1.56 to $4.12 \mathrm{~L} / \mathrm{d}$ and almost similar type of observations was recorded for milk production in non-descript cows, crossbred cows and buffaloes in eastern region by Singh et al., (2005), Roy and Saha, (2003). In this study, the buffaloes were indigenous type but milk production was good compared to cattle. Birth weight, weaning weight, weaning and slaughter age of indigenous buffalo in selected areas were $27.5 \mathrm{~kg}$, $56.5 \mathrm{~kg}$ and 14, 55 months respectively. The weaning and slaughter age of buffaloes was almost close in indigenous and crossbred buffaloes but higher than cattle.

\section{Reproductive performances}

The reproductive parameters that are age at first heat, age at first pregnancy, age at first calving, gestation period, number of service per conception and inter calving period of buffaloes in the selected area are shown in Table 3. In this study, almost hundred percent respondents said the average age at first heat and first pregnancy that was puberty of buffaloes was almost similar (3.4 years). The gestation period of buffaloes in selected area was 10 months. The average number of service per conception was 3.1 times. The average post-partum heat period was 4.9 months and inter calving period was 15.8 months found in this investigation.

\section{Major diseases}

Four major diseases of buffaloes were found where the incidence of foot and mouth diseases (FMD) was
63\% followed by anthrax (15\%), black quarter (BQ) (12\%) and hemorrhagic septicemia (HS) (10\%). Incidence of diseases is a major constraint of livestock production which not only reduces the productivity but also causes economic loss. Mitra et al., (1995), Sarker et al., (2013) and Gupta et al., (2014) also reported that a serious threat of infectious diseases like FMD, HS and BQ in animals were the main problem. Hence, proper support is required for vaccination against some epidemic viral and bacterial diseases for their prevention and control. No buffalo farmers were claimed for early or endemic mastitis but common diseases like scours, pneumonia, navelill, ecto and endo parasites (tick, lice, mice, round worm, tape worm, lung worm), blot, diarrhoea and anemia were noticed. However, very dangerous scenario was found that all the farmers of the selected area were totally unaware about vaccination and de-worming and they did not follow any vaccination and de-warming programme.

Table 3. Reproductive performances of buffaloes in Subornochar

\begin{tabular}{lc}
\hline Parameters & Time/Period \\
\hline Age at 1st heat (year) & 3.4 \\
Age at $1^{\text {st }}$ pregnancy (year) & 3.8 \\
Age at 1 ${ }^{\text {st }}$ calving (year) & 4.51 \\
Gestation period (month) & 10.0 \\
Number of Service per conception (times) & 3.1 \\
Post partum heat period (month) & 4.9 \\
Inter calving period (month) & 15.8 \\
\hline
\end{tabular}

\section{Feeding and management of buffaloes}

\section{Availability of feeds and feeding systems}

Availability, source of feeds and fodder and feeding methods are presented in Table 4. Majority of the farmers have expressed availability of the feeds and fodder was the major problem for buffalo rearing, agreed with the result of Sathyanarayan et al., (2010). Most of the respondents were fully dependent on roadside and grasses (durba, hishra etc.) in the unused land, rest of the respondents were used cut and carry grasses, water hyacinth, tree leaves and urigash. Rice straw is the main feed source of buffaloes in selected areas. No farmers were found to supply concentrate to their buffaloes. 
Like study areas of Bagerhat districts in Bangladesh majority of the farmers were fully dependent on grazing (Sarker et al., 2013). Majority of the respondents kept their buffaloes mainly with extensive system and bathan and very little percentage of the farmer practiced semiintensive system in the study areas.

Table 4. Availability of feeds and feeding system of buffaloes in Subornochar

\begin{tabular}{llc}
\hline Parameters & Category & $\begin{array}{c}\text { Percentage of } \\
\text { respondents }\end{array}$ \\
\hline Availability & Available & 30 \\
of feeds & Not available & 70 \\
& Total & 100 \\
\cline { 2 - 3 } & Roadside and unused landed & 80 \\
Source & grass & 20 \\
of feed & Cut and carry grass & 0.0 \\
& Concentrates & 100 \\
\cline { 2 - 3 } Feeding & Total & 80 \\
method & Extensive and Bathan & 20 \\
& Semi-intensive & 0.0 \\
& Intensive & 100 \\
\hline
\end{tabular}

\section{Chemical composition of feedstuffs}

The chemical compositions of the available feedstuffs fed to buffaloes in Subornochar areas are presented in Table 5. Uri grasses are very soft and are commonly available in the bank of river or see shore. The CP of uri grass was found highest compared with all other available. The CP content of broken rice, broken wheat, rich polish, wheat bran, straw, uri grass, durba grasses, hishra and water hyacinth were found higher compared to other unconventional grasses. The findings of $\mathrm{CP}$ values were comparable and even higher than those of other unconventional fodder leaves and higher than the minimum range of NRC for mature beef cattle $(70 \mathrm{~g} / \mathrm{kg})$ and high producing dairy cows $(190 \mathrm{~g} / \mathrm{kg})$. The CF content of the feedstuffs in the selected areas was lower, indicated a good quality feeds for buffaloes. The presence of high amount of CF in feeds reported to decrease dry matter digestibility in animals and therefore provides a good indication of the nutritional value of the feed material. The highest ether extract content was recorded in rice polish and the lowest was found in uri grass.

\section{Cost-benefit of buffalo rearing}

\section{Cost of buffaloes}

The price of buffaloes varies according to the size, body condition, milk production and utility. The price of a pair of buffaloes for dual purpose ranged from Tk. 80000.00 to 180000.00 in this study area. Sarkar et al., (2013) found the price of a pair of buffaloes for draught purpose ranged from Tk. 60000.00 to 200000.00 in Bagerhat district, which is almost similar with the present study.

\section{Management cost}

The cost of feeding, breeding, housing, equipment and healthcare of buffaloes are presented in Table 6. Per year cost of housing and equipment was almost similar with feed cost. Farmers generally bred their buffaloes naturally with buffalo bull. For this reason, the breeding cost was low. On the other hand, they did not purchase any feed for buffalo except the scarcity period, that time they purchase straw only. The major cost of healthcare was medicinal cost. The total rearing cost of one buffalo per year was Tk. 6850.00. Sarkar et al., (2013) reported that the rearing cost of one buffalo was Tk. 5070.00 in Bagerhut district in Bangladesh. The rearing cost was found higher in Subornochar than that from Bagerhat.

\section{Cost for family members}

The major costs of family members are presented in Table 7. Highest cost was found for purchasing food among the total expenditure followed by education, maintaining social status, health care and clothing. The housing cost was found to be lowest among the expenditure.

\section{Income from buffalo rearing}

The total (draught + milk) and net income per year per buffalo are presented in Table 8 . The annual average income per year per buffalo for draught and milk was Tk. 15000.00 and 12000.00 BDT, respectively. In India and Bangladesh, net annual income from rearing one cross breed cow (Kalash et al. 2009) and one buffalo (Sarkar et al., 2013) was Rs. 30784.00 and Tk. 15630.00 BDT per year, 
respectively. In this study, the net income from one rearing buffaloes in the selected areas was profitable. buffalo per year was 13920.00 BDT indicated that

Table 5. Chemical composition of feedstuffs fed to buffaloes in Subornochar areas

\begin{tabular}{|c|c|c|c|c|c|c|c|c|c|}
\hline \multirow[t]{2}{*}{ Name of the feedstuff } & \multicolumn{9}{|c|}{ Chemical composition (\% DM basis) } \\
\hline & DM & OM & $\mathrm{CP}$ & CF & ADF & NDF & $\mathrm{EE}$ & NFE & Ash \\
\hline Broken rice & 87.4 & 84.2 & 9.3 & 23.6 & 2.9 & 12.0 & 2.1 & 61.8 & 3.2 \\
\hline Broken wheat & 88.5 & 82.9 & 12.5 & 29.6 & 3.7 & 14.2 & 2.9 & 49.4 & 5.6 \\
\hline Rice polish & 93.4 & 78.0 & 10.8 & 12.8 & 13.3 & 33.0 & 10.6 & 50.4 & 15.4 \\
\hline Wheat bran & 96.0 & 87.0 & 14.8 & 14.0 & 14.8 & 43.1 & 4.9 & 57.3 & 9.0 \\
\hline Straw & 86.5 & 71.6 & 3.9 & 35.9 & 20.5 & 70.3 & 1.4 & 43.9 & 14.9 \\
\hline Uri grass & 89.9 & 72.8 & 26.6 & 26.7 & 17.7 & 26.2 & 1.1 & 28.5 & 17.1 \\
\hline Dhubla/durba grass & 90.3 & 78.7 & 17.3 & 34.2 & 17.7 & 30.4 & 1.6 & 35.2 & 11.6 \\
\hline Hishra grass & 91.0 & 76.3 & 19.4 & 26.5 & 19.1 & 27.9 & 2.6 & 36.9 & 14.7 \\
\hline Water hyacinth & 89.5 & 76.0 & 13.4 & 13.7 & 15.6 & 28.4 & 2.6 & 56.9 & 13.5 \\
\hline
\end{tabular}

Table 6. Management cost of one buffalo per year in Subornochar

\begin{tabular}{lc|}
\hline \multicolumn{1}{c}{ Category } & Expenditure (BDT) \\
\hline Average feed cost (year) & 3050.0 \\
Average breeding cost (year) & 300.0 \\
Average cost of housing and equipment & 2500.0 \\
(year) & 5850.0 \\
Total & \\
\hline Medicine and vaccine cost & 500.0 \\
\hline Average cost of medicine (year) & 000.0 \\
Average cost of vaccine (year) & 500.0 \\
Total healthcare cost & 6850.0 \\
\hline Total rearing cost & \\
\hline
\end{tabular}

Table 7. Average yearly expenditure of family members in Subornochar

\begin{tabular}{lc}
\hline \multicolumn{1}{c}{ Category } & Average expenditure (BDT) \\
\hline Food & 1878.00 \\
Cloth & 711.00 \\
House & 350.00 \\
Education & 1276.00 \\
Health care & 751.00 \\
Maintaining social status & 1252.00 \\
\hline Total & $\mathbf{6 2 1 8 . 0 0}$ \\
\hline
\end{tabular}

Table 8. Total and net income (BDT) from buffalo per year in Subornochar

\begin{tabular}{ll}
\hline Category & Income (BDT) \\
\hline Income/buffalo/year (Draught \& Milk) & $15000.00+12000.00=$ \\
Total expenditure = (Rearing cost + & $6850.0+6218.00=$ \\
Expenditure) & 13068.00 \\
Net income $=($ Income - Expenditure $)$ & $27000.00-13068.00=$ \\
& 13932.00 \\
\hline
\end{tabular}

Livelihood improvement and impact of buffalo farmers

Before rearing buffaloes, the farmers spent only Tk. 1280.00, 980.00, 1120.00, 1150.00, 710.00 and 320.00 for purchasing food, cloth, social status, education, health care and housing, respectively but they were able to spent Tk. 3050.00, 1720.00, 2650.00, 2710.00, 1270.00 and 450.00 , respectively after they started rearing buffaloes, which was 43.38, 43.02, 57.73, 57.56, 44.09 and $28.88 \%$ higher than the previous state, respectively. This result clearly indicated that livelihood status of buffalo farm families are improved through buffalo rearing in Subornochar areas especially for the farm women and the development of this sector was the potential path to rural prosperity (Kalash et al., 2009). Sarkar et al., (2013) reported that the educational and social status, health care, housing cost of the buffalo farmers was also improved through buffalo rearing in Bagerhat.

\section{Conclusion}

Considering all the studied parameters, buffalo rearing was a profitable practice in the selected areas and improve the socio-economic status, purchasing capacity of food and cloths, impact on social status, health care, education, housing of buffalo farmers.

\section{Acknowledgement}

The authors are gratefully acknowledge the help and support for funding and other infrastructural facilities 
provided by the Krishi Gobesona Foundation (KGF), BARC campus, Farmgate, Dhaka in carrying out this research work. Thanks to buffalo farmers of Subornochar for their cooperation in data collection.

\section{References}

Agarwal N, Kamra DN, Chatterjee PN, Ravindra K, Chaudhary LC (2008). In vitro methanogenesis, microbial profile and fermentation of green forages with buffalo rumen liquor as influenced by 2bromoethanesulphonic acid, Asian Australian Journal of Animal Science 21: 818-823.

AOAC (2004). Association of Official Analytical Chemists, Official Methods of Analysis, $17^{\text {th }}$ Edition, Arlington, VA.

Bartocci S, Amici A, Verna M, Terramoccia S, Martillotti F (1997). Solid and fluid passage rate in buffalo, cattle and sheep fed diets with different forage to concentrate ratios. Livestock Production Science, 52: 201-208.

BBS (2012). Bangladesh Bureau of Statistics, Statistics Division, Ministry of Planning, Dhaka, Bangladesh.

BER (2012). Bangladesh Economic Review, Economic Advisers Wing, Finance Division, Ministry of Finance, Government of the People's Republic of Bangladesh (mof.gov.bd/en/index.php?option=com_con tent\&view=article\&... , accessed, 2015).

DLS (2013). Department of Livestock Services, Annual report on livestock, Division of Livestock Statistics, Ministry of Fisheries and Livestock, Farmgate, Dhaka, Bangladesh.

Ghaffar A, Khan MI, Mirza MA, Prizada WH (1991). Effect of year and calving season on some traits of economic importance in Nili-Ravi buffaloes. Pakistan Journal of Agricultural Research, 12(3): 217.

Goering HK, Van Soest PJ (1970). Forage fiber analysis (Apparatus, reagent, procedures and some applications). Agriculture Handbook, No. 379, ARS-USDA, Washington, DC.
Gupta JJ, Singh KM, Bhatt BP, Dey A (2014). A Diagnostic Study on Livestock Production System in Eastern Region of India.ICAR Research Complex for Eastern Region P.O. Bihar Veterinary College, Patna-800014 (Bihar).

Hussain I, Cheeke PR (1996). Evaluation of annual ryegrass straw: corn juice silage with cattle and water buffalo: digestibility in cattle vs. buffalo, and growth performance and subsequent lactational performance of Holstein heifers. Animal and Feed Science Technology, 57:195-202.

Kalash P, Rathore R, Kumar M (2009). Livelihood Improvement of Farm Women through Cattle and Buffalo Rearing in Jhunjhunu District of Rajasthan. International Journal of Rural Studies, 16: 1-3.

Mitra M, Ghosh D, Ali K, Guha C, Pramanik AK (1995). Prevalence of sub-clinical mastitis in an organized buffalo farm at Haringhata. Indian Veterinary Journal, 72: 1310-1311.

NARS (2010). National Agricultural Research System; Vision -2030 and beyond. Bangladesh Agricultural Research Council, Farmgate, Dhaka, Bangladesh.

Roy PK, Saha RC (2003). Association of certain body measurements with some economic traits in Jersey $\mathrm{x}$ Tharparkar/Red Sindhi crossbred cows. Indian Journal of Dairy Science, 56: 338-340.

Sarker S, Hossain MM, Amin MR (2013). Socioeconomic status of buffalo farmers and the management practices of buffaloes in selected areas of Bagerhat district of Bangladesh. Bangladesh Journal of Animal Science, 42: 158-164.

Sathynarayan K, Jagadeeswary V, Chandrashekhar V, Murthy, Wilfred RS, Sudha G (2010). Socio-economic status of livestock farmers of Narasapura village - A Benchmark Analysis. Veterinary World, 3: 215-218.

Singh KM, Singh RKP, Meena MS, Kumar A, Kumar AK, Anjani (2011). A village level study of poverty in Bihar: using panel data approach. MPRA Paper No. 45232. ICAR 
Research Complex for Eastern Region, Patna.

Singh KM, Singh RKP, Meena MS, Kumar A, Kumar AK, Anjani (2012). Rural poverty in Jharkhand: an empirical exploration of socio-economic determinants. MPRA Paper No. 44811. ICAR Research Complex for Eastern Region, Patna.

Singh RB, Saha RC, Ghosh MK (2005). Nutritional needs of dairy cattle in eastern and northeastern India for sustainable milk production. In Technological interventions for socio-economic enrichment of rural dairy farmers in eastern and north-eastern India, NDRI Kalyani, Nadia, West Bengal.

Terramoccia S, Bartocci S, Amici A, Martillotti F (2000). Protein and protein-free dry matter rumen degradability in buffalo, cattle and sheep fed diets with different forage to concentrate ratios. Livestock Production Science, 65: 185 -195. 